\title{
Dry Etching Characteristics of ZnO Thin Films for the Optoelectronic Device by Using Inductively Coupled Plasma
}

\author{
Young-Hee Joo, Jong-Chang Woo, and Chang-II Kim ${ }^{\dagger}$ \\ School of Electrical and Electronics Engineering, Chung-Ang University, Seoul 156-756, Korea
}

Received September 15, 2011; Revised November 18; 2011; Accepted November 21; 2011

In this study, we carried out an investigation of the etching characteristics (etch rate, selectivity to $\mathrm{SiO}_{2}$ ) of $\mathrm{ZnO}$ thin films in $\mathrm{N}_{2} / \mathrm{Cl}_{2} / \mathrm{Ar}$ inductivity coupled plasma. A maximum etch rate and selectivity of $108.8 \mathrm{~nm} / \mathrm{min}$ and, 3.21 , respectively, was obtained for $\mathrm{ZnO}$ thin film at a $\mathrm{N}_{2} / \mathrm{Cl}_{2} / \mathrm{Ar}$ gas mixing ratio of 15:16:4 sccm. The plasmas were characterized by optical emission spectroscopy. The $\mathrm{x}$-ray photoelectron spectroscopy analysis showed the efficient destruction of oxide bonds by ion bombardment. An accumulation of low volatile reaction products on the etched surface was also shown. Based on this data, an ion-assisted chemical reaction is proposed as the main etch mechanism for plasmas containing $\mathrm{Cl}_{2}$.

Keywords: $\mathrm{ZnO}$, ICP, OES, XPS, $\mathrm{Cl}_{2}$

\section{INTRODUCTION}

Nowadays, Zinc Oxide $(\mathrm{ZnO})$ thin films are widely used in various applications, such as optoelectronic devices, including display devices and solar cells. $\mathrm{ZnO}$ has a wide direct band gap $(\mathrm{Eg}=$ $3.37 \mathrm{eV}$ ) and its exaction binding energy is higher $(60 \mathrm{meV})$ than that of $\mathrm{GaN}$ ( $25 \mathrm{meV}$ ). $\mathrm{ZnO}$ thin films have a hexagonal (wurtzite) crystal structure with $\mathrm{a}=3.25 \AA, \mathrm{c}=5.12 \AA$ and their Hall mobility is $200 \mathrm{~cm}^{2} /(\mathrm{V} \cdot \mathrm{s})$ at room temperature. Also, the high radiation resistance of $\mathrm{ZnO}$ thin films makes them suitable for sensors, aerospace devices and nuclear applications [1-3]. In the fabrication of optoelectronic devices, $\mathrm{ZnO}$ thin films have to undergo an etching process, a critical step in making a pattern. Conventional wet etching shows an isotropic etching profile. However, as the size of the device features becomes smaller, wet etching becomes less and less suitable, and is particularly unsuitable for nano scale line widths due to the isotropic properties and this kind of

${ }^{\dagger}$ Author to whom all correspondence should be addressed: E-mail: cikim@cau.ac.kr

Copyright $\odot 2012$ KIEEME. All rights reserved.

This is an open-access article distributed under the terms of the Creative Commons Attribution Non-Commerciad License (http://creativecommons.org/licenses/by-nc/3.0) which permits unrestricted noncommercial use. etching displays. On the other hand, dry etching is distinguished by its anisotropic profile. As a result, the dry etching process is suitable for micro feature size line widths and high aspect ratios.

In this study, $\mathrm{ZnO}$ thin films were etched with $\mathrm{N}_{2} / \mathrm{Cl}_{2} / \mathrm{Ar}$ gas in inductivity coupled plasma (ICP). The characteristics of etching on $\mathrm{ZnO}$ thin films were investigated in terms of etch rate and selectivity with various processing parameters, including the gas mixing ratio, RF power, bias power, and process pressure. The plasmas were characterized using optical emission spectroscopy (OES) analysis. The chemical binding states in the surface of the etched $\mathrm{ZnO}$ thin films were investigated with $\mathrm{X}$-ray photoelectron spectroscopy (XPS).

\section{EXPERIMENTS}

The $\mathrm{ZnO}$ thin films used in this work were deposited on the 6" Si substrates by atomic layer chemical vapor deposition [4]. The final thickness of the $\mathrm{ZnO}$ thin films was about $200 \mathrm{~nm}$. The etching experiments were performed in a planar ICP system whose schematic is shown in Fig. 1. The ICP system consists of a chamber, electrodes, gas supply, mass flow controller and turbo molecular pump. We investigated the etch rate of the $\mathrm{ZnO}$ thin films under various experimental conditions. A process variables 


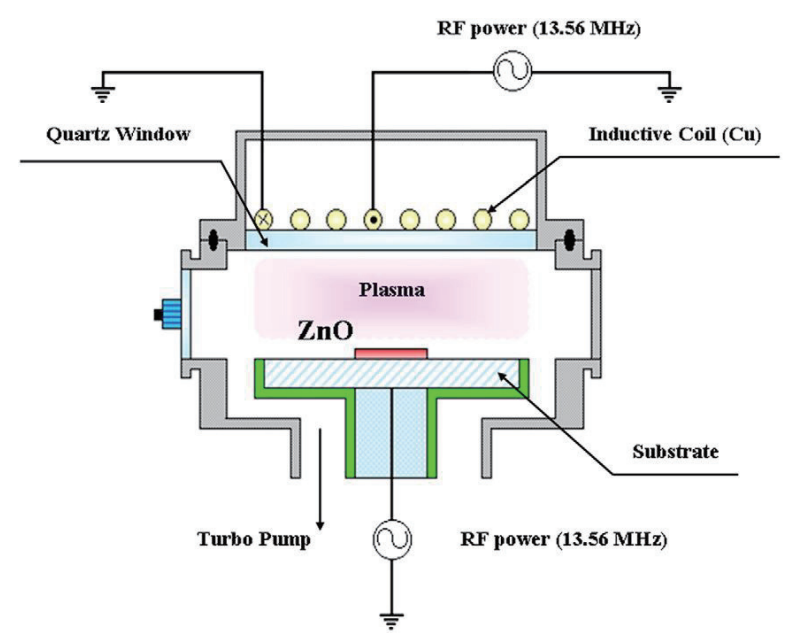

Fig. 1. Schematic diagram of the high density plasma system.

Table 1. Process conditions.

\begin{tabular}{cc}
\hline Process parameter & Parameter range \\
\hline Gas mixture & $\mathrm{N}_{2} / \mathrm{Cl}_{2} / \mathrm{Ar}$ \\
Source power & $700 \sim 900 \mathrm{~W}$ \\
Bias power & $300 \sim 500 \mathrm{~W}$ \\
Process pressure & $1 \sim 3 \mathrm{~Pa}$ \\
\hline
\end{tabular}

was fixing the gas mixing ratio at $\mathrm{Cl}_{2} / \mathrm{Ar}(16: 4 \mathrm{sccm})$. The gas mixing ratio was varied to find how it influenced the etching. In addition, plasma etching of $\mathrm{ZnO}$ films was investigated by changing the etching parameters included in Table 1 . The additive $\mathrm{N}_{2}$ gas flow rate was increased from $5 \mathrm{sccm}$ to $20 \mathrm{sccm}$ in steps of $5 \mathrm{sccm}$. The base condition of the experiment consists of four basic parameters: a flow rate of $20 \mathrm{sccm}$, RF power of $800 \mathrm{~W}$, bias power of $400 \mathrm{~W}$, and process pressure of $2 \mathrm{~Pa}$. The experiments were performed by changing a specific parameter while maintaining the other parameters in their base condition. A surface profiler ( $\alpha$-step 500, KLA Tencor) was used to determine the etch rate of the $\mathrm{ZnO}$ thin films. Changes to the chemical composition in the chamber were analyzed with an OES (SC TECH, PCM 420). The chemical reactions on the surface of the etched $\mathrm{ZnO}$ thin films, were determined by XPS (SIGMA PROBE, Thermo VG) with $\mathrm{Al} \mathrm{K \alpha}(1,486.6 \mathrm{eV})$ radiation at $300 \mathrm{~W}$. The XPS equipment consisted of a micro focused monochromatic source and electron gun with a power of $15 \mathrm{kV}$. All XPS samples consisted of $\mathrm{ZnO}$ thin film with a size of $1 \times 1 \mathrm{~cm}^{2}$.

\section{RESULTS AND DISCUSSION}

For the characterization of $\mathrm{ZnO}$ thin film in an ICP system, the plasma etching of $\mathrm{ZnO}$ thin film and $\mathrm{SiO}_{2}$ were systematically investigated in regards to the $\mathrm{N}_{2} / \mathrm{Cl}_{2} / \mathrm{Ar}$ gas mixing ratio. Figure 2 shows the etch rate on the $\mathrm{ZnO}$ thin film and the selectivity of the $\mathrm{ZnO}$ to $\mathrm{SiO}_{2}$ as a function of the $\mathrm{N}_{2}$ content in the $\mathrm{Cl}_{2} / \mathrm{Ar}$ plasma. The etch rate of the $\mathrm{ZnO}$ thin film at an $\mathrm{N}_{2}$ flow rate of $0 \mathrm{sccm}$ was $82.5 \mathrm{~nm} / \mathrm{min}$ and the selectivity was 3.21 . As the $\mathrm{N}_{2}$ content was increased up to $15 \mathrm{sccm}$, the etch rate and selectivity of the $\mathrm{ZnO}$ thin film increased to $108.5 \mathrm{~nm} / \mathrm{min}$ and, 3.98, respectively. On the contrary, the etch rate of the $\mathrm{ZnO}$ thin film was decreased to $92.7 \mathrm{~nm} / \mathrm{min}$ and the selectivity to 3.34 when the $\mathrm{N}_{2}$ flow rate set to $20 \mathrm{sccm}$. The chemical reactions on the surface of the etched $\mathrm{ZnO}$ thin film in the $\mathrm{Cl}_{2} / \mathrm{Ar}$ plasma included the creation of $\mathrm{Zn}_{\mathrm{x}} \mathrm{Cl}_{\mathrm{y}}$ from the $\mathrm{Cl}$ radicals [4,5]. The $\mathrm{N}$ atom has a very low

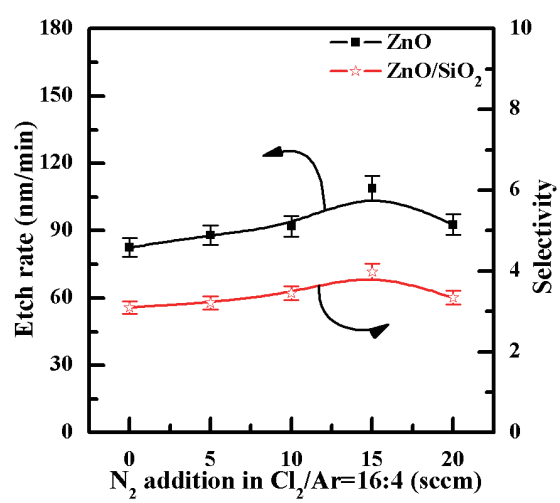

Fig. 2. Etch rate of $\mathrm{ZnO}$ thin film and selectivity of $\mathrm{ZnO}$ to $\mathrm{SiO}_{2}$ as a function of $\mathrm{N}_{2} / \mathrm{Cl}_{2} /$ Ar gas mixing ratio.

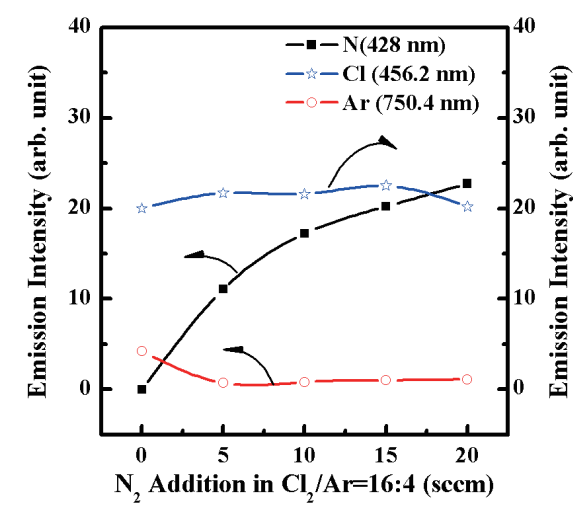

Fig. 3. The optical emission spectroscopy of ion density as a function of gas mixing ratio.

electron affinity $(7 \mathrm{KJ} / \mathrm{mol})$ and lighter atomic weight $(14.0067$ $\mathrm{g} \cdot \mathrm{mol}^{-1}$ ) compared to Ar (39.948 g. $\left.\mathrm{mol}^{-1}\right)$. Furthermore, the ionized $\mathrm{N}$ atoms would be expected to play the role of a physical etch through the bombardment of ions such as Ar ions. The ion bombardment by the $\mathrm{N}$ ions supported the chemical reaction of $\mathrm{Cl}_{2}$ in conjunction with the Ar ion by breaking the oxide bonds [5-7] In addition, we assume that reaction a product exists in the form of $\mathrm{N}_{\mathrm{x}} \mathrm{O}_{\mathrm{y}}$, and $\mathrm{ZnxNy}$ [8-12], even though the electron affinity of $\mathrm{N}$ is very low. In this paper our focus is on the role of the additive $\mathrm{N}_{2}$ gas. In our opinion, the results of experiments performed by varying the etch rate suggests that the $\mathrm{N}_{2}$ gas induced both physical etching and chemical reactions on the surface of the $\mathrm{ZnO}$ thin films $[13,14]$. In our opinion, the increasing etching rate in $\mathrm{N}_{2} / \mathrm{Cl}_{2} / \mathrm{Ar}$ plasma at higher $\mathrm{N}_{2}$ flow rates may be explained by two factors. The first factor is connected with the $\mathrm{N}_{2}$ gas assisting the physical Ar sputtering of both the main material, the $\mathrm{ZnO}$ film in this case, and the surface layer of the reaction products. The contribution to physical sputtering in the etching process is confirmed by the fact that the etching rate using a $\mathrm{N}_{2}$ mixed gas chemistry is higher than in $\mathrm{Cl}_{2} / \mathrm{Ar}$ gas chemistry. The second factor is connected with the acceleration of chemical interaction due to the increasing reaction probability and destruction of $\mathrm{Zn}-\mathrm{O}$ bonds. The higher concentration of reactive $\mathrm{Cl}$ species in the $\mathrm{N}_{2}$ content plasma causes the etch rate to increase. The $\mathrm{ZnO}$ thin film etch rate is strongly dependent on the $\mathrm{Cl}$ radical concentration, due to the higher vapor pressure of the metal chlorides in $\mathrm{Zn}-\mathrm{Cl}$. However, when the $\mathrm{N}_{2}$ flow rate was $20 \mathrm{sccm}$, the etch rate decreased because the probability of reactions such as $\mathrm{N}-\mathrm{O}$ or $\mathrm{Zn}-\mathrm{O}$ are increased more than the $\mathrm{Zn}-\mathrm{Cl}$ reaction.

Figure 3 shows the optical emission intensity of additive $\mathrm{N}_{2}$ 


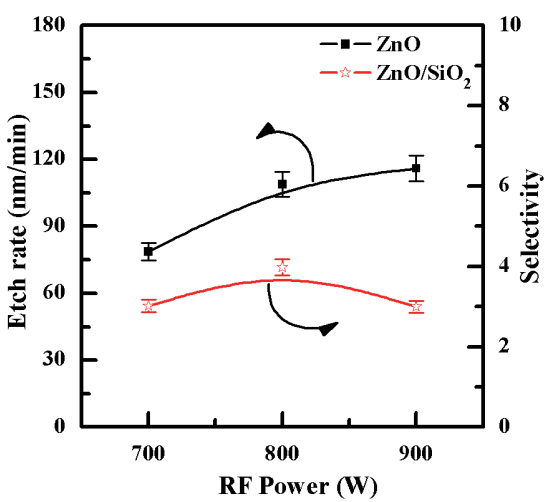

Fig. 4. Etch rate of $\mathrm{ZnO}$ thin film and selectivity of $\mathrm{ZnO}$ to $\mathrm{SiO}_{2}$ as a function of RF power.

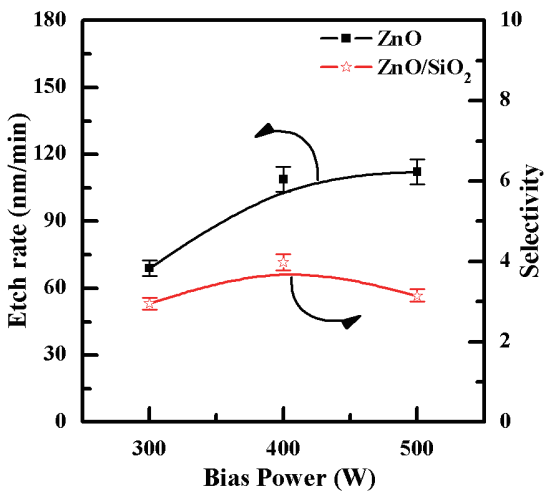

Fig. 5. Etch rate of $\mathrm{ZnO}$ thin film and selectivity of $\mathrm{ZnO}$ to $\mathrm{SiO}_{2}$ as a function of bias power.

gas flow at a fixed $\mathrm{Cl}_{2} / \mathrm{Ar}(16: 4 \mathrm{sccm})$ ratio. These lines for $\mathrm{Ar}$ [750 nm], $\mathrm{Cl}$ [452.6 nm] and $\mathrm{N}$ [428 nm] are frequently used for analytical purposes including optical emission actinometrical to determine the absolute densities of active particles. For the $\mathrm{N}_{2} /$ $\mathrm{Cl}_{2} / \mathrm{Ar}$ plasma, $\mathrm{Cl}$ emission intensity increased with increasing $\mathrm{N}_{2}$ gas flow up to $15 \mathrm{sccm}$. Also the $\mathrm{N}_{2}$ emission intensity shows an increasing trend with increasing $\mathrm{N}_{2}$ content in the $\mathrm{Cl}_{2} / \mathrm{Ar}$ mixture. As a result, Fig. 2 shows the effect of $\mathrm{N}_{2}$ content on the etch rate and selectivity.

Figure 4 shows the etch rate of the $\mathrm{ZnO}$ thin films and the selectivity of $\mathrm{ZnO}$ to $\mathrm{SiO}_{2}$ as a function of the RF Power. The etch rate of the $\mathrm{ZnO}$ thin film increased from $78.6 \mathrm{~nm} / \mathrm{min}$ to 115.9 $\mathrm{nm} / \mathrm{min}$ as the RF power was increased from $700 \mathrm{~W}$ to $900 \mathrm{~W}$. The selectivity of the $\mathrm{ZnO}$ to $\mathrm{SiO}_{2}$ increased from 3.0 to 3.98 as the RF power was increased from $700 \mathrm{~W}$ to $800 \mathrm{~W}$. However, the selectivity decreased back to 3.0 at an RF power of $900 \mathrm{~W}$. This implies that the RF power affects the $\mathrm{SiO}_{2}$ thin film more than the $\mathrm{ZnO}_{2}$ thin film. Generally, the etch rate increased as the $\mathrm{RF}$ power increased. A high RF power allows more electrons to collide with the $\mathrm{Cl}_{2} / \mathrm{Ar}$ molecules. For this reason, a high $\mathrm{RF}$ power enhances the dissociation rate of the injected $\mathrm{Cl}_{2} / \mathrm{Ar}$ molecules in the reaction chamber. As a result, the dissociation of the $\mathrm{Cl}_{2} /$ Ar molecules and activated ions increases the plasma density. In conclusion, increases in the amount of $\mathrm{Ar}$ and $\mathrm{N}$ ions and reactive $\mathrm{Cl}_{2}$ radicals increases the etch rate by means of reactive ion etching.

Figure 5 shows the etch rate of the $\mathrm{ZnO}$ thin films and selectivity of the $\mathrm{ZnO}$ to $\mathrm{SiO}_{2}$ as a function of the bias power. The etch rate of the $\mathrm{ZnO}$ thin films increased from 69 to $112.2 \mathrm{~nm} / \mathrm{min}$ as the bias power increased from $300 \mathrm{~W}$ to $500 \mathrm{~W}$. The ion bombard-

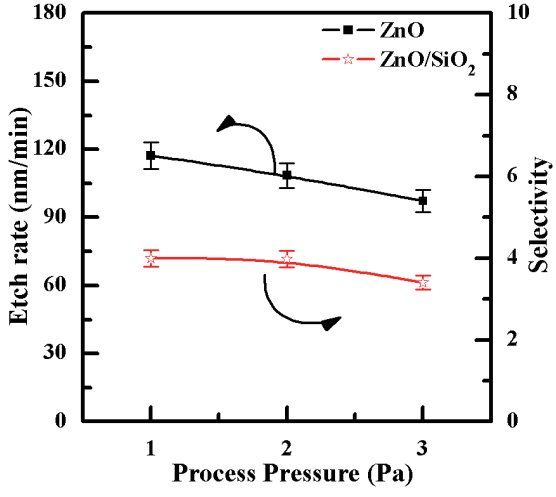

Fig. 6. Etch rate of $\mathrm{ZnO}$ thin film and selectivity of $\mathrm{ZnO}$ to $\mathrm{SiO}_{2}$ as a function of process pressure.

ment and the energy of the ion flux are critical factors in improving the etch rate. The physical sputtering by ion bombardments is associated with the bias power. The selectivity of the $\mathrm{ZnO}$ to $\mathrm{SiO}_{2}$ increased from 2.95 to 3.98 as the bias power was increased from $300 \mathrm{~W}$ to $400 \mathrm{~W}$. The selectivity at a bias power of $500 \mathrm{~W}$ was decreased to 3.15. In our opinion, this phenomenon is caused by saturated ions and radicals in the reaction chamber. Further increasing the amount of ions and radicals improved the etch rate, however this also caused an increase in the pressure of the reaction chamber and in the density of the plasma. The increased chamber pressure makes the mean free path of the radicals and ions too short for a sufficient number of them to arrive at the $\mathrm{ZnO}$ surface. In addition, by-products after the chemical reactions remain on the surface of the film instead of being efficiently removed from the reaction chamber. The decrease of the etch rate can be attributed to factors such as the short mean free path caused by the increased pressure and the inefficient removal of by-products.

Figure 6 shows the etch rate of the $\mathrm{ZnO}$ thin films and selectivity of $\mathrm{ZnO}$ to $\mathrm{SiO}_{2}$ as a function of the process pressure. The etch rate decreased as the pressure increased. In concrete terms, the etch rate of the $\mathrm{ZnO}$ thin films decreased from 117.2 to $97.2 \mathrm{~nm} /$ $\mathrm{min}$ as the process pressure increased from $1 \mathrm{~Pa}$ to $3 \mathrm{~Pa}$. The etching tendency of $\mathrm{SiO}_{2}$ is similar to that of the $\mathrm{ZnO}$ thin film. As a result, the selectivity remained between troughly 4 and 3.14. If the process pressure is low enough, the mean free paths of the ions and radicals is sufficiently long. In these conditions, the ions and radicals can avoid colliding with other ions and radicals until they arrive at the substrate.

Figure 7 shows the XPS narrow scan spectra of the (a) Zn 2p, (b) $\mathrm{O} 1 \mathrm{~s} \mathrm{(c)} \mathrm{Cl} 2 \mathrm{p}$ and (d) $\mathrm{N}$ 1s peaks of the etched $\mathrm{ZnO}$ thin films as a function of the gas mixing ratio. As shown in Fig. 7(a), the Zn $2 \mathrm{p}$ peak of the as-deposited $\mathrm{ZnO}$ thin films decomposes into two peaks at binding energies of $1,021.75 \mathrm{eV}\left(\mathrm{Zn} 2 \mathrm{p}_{3 / 2}-\mathrm{O}\right)$ and $1,044.95$ $\mathrm{eV}\left(\mathrm{Zn} 2 \mathrm{p}_{1 / 2}-\mathrm{O}\right)$. After etching, the position of the $\mathrm{Zn} 2 \mathrm{p}$ picks were shifted by $\pm 0.4 \mathrm{eV}$ toward a lower binding energy compared with the as-deposited sample. This chemical shift indicates that fewer $\mathrm{Zn}-\mathrm{Cl}$ bonds were present in the $\mathrm{ZnO}$ thin film surface. This shift of the peaks brought them closer to the binding energy of metallic $\mathrm{Zn}$ than that of the $\mathrm{Zn}-\mathrm{Cl}$ bond. According to previous reports, the shift of the peak toward a higher binding energy means that $\mathrm{Zn}-\mathrm{Cl}$ bonds exist in the surface. In our opinion, the physical etching ratio is higher than the chemical etching ratio. Therefore, we believe the $\mathrm{Ar}$ ions destroyed the $\mathrm{Zn}-\mathrm{O}$ bonds and the $\mathrm{Cl}$ radicals also reacted with the $\mathrm{O}$ atoms rather than the $\mathrm{Zn}$ atoms. As such, by-products such as $\mathrm{Cl}_{\mathrm{x}} \mathrm{O}_{\mathrm{y}}$ were removed from the $\mathrm{ZnO}$ thin film surface by the turbo molecular pump or the metallic $\mathrm{Zn}$ atoms remain until they react with the remaining $\mathrm{O}$, 

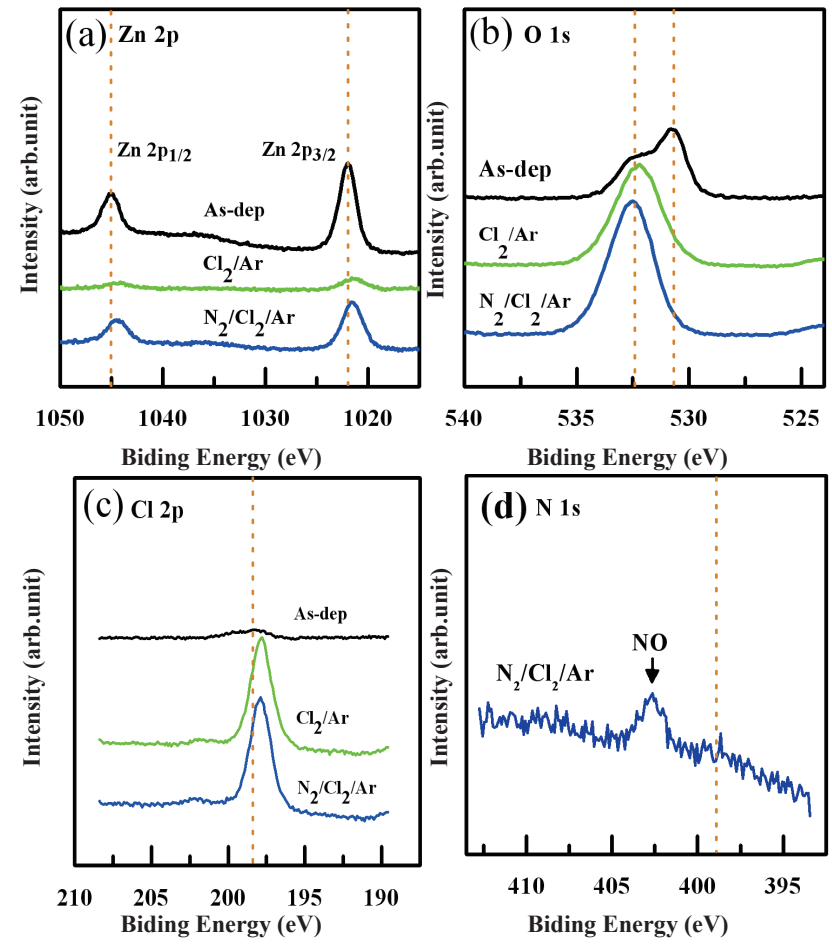

Fig. 7. XPS narrow scan spectra of the etched $\mathrm{ZnO}$ thin film surface (a) Ti 2p, (b) O 1s, (c) Cl 2p, (d) N 1s.

$\mathrm{Cl}$, and $\mathrm{N}$ atoms. Also, we assume that $\mathrm{Zn}$ was bound to $\mathrm{Cl}$ or $\mathrm{N}$ at a low binding energy so that the $\mathrm{Zn}-\mathrm{Cl}$ bond peak overlapps with the $\mathrm{Zn}-\mathrm{O}$ peak at $1,021.5 \mathrm{eV}$. As shown in Fig. 7(b), the O peaks are shifted toward a higher binding energy. We suggest that the amount of $\mathrm{O}-\mathrm{O}$ bonds was increased in the surface. This suggests that the Ar ions break the $\mathrm{Zn}-\mathrm{O}$ bonds and the separated $\mathrm{O}$ atoms recombine with other $\mathrm{O}$ atoms. This phenomenon is caused by the fact that $\mathrm{O}$ has a higher electron affinity than $\mathrm{Zn}$. The $\mathrm{O}$ 1s peak of the as-deposited sample was decomposed into two peaks corresponding to the $\mathrm{Zn}-\mathrm{O}$ bond $(530.8 \mathrm{eV})$ and the $\mathrm{O}-\mathrm{O}$ bond ( $532.5 \mathrm{eV}$ ). After the $\mathrm{Cl}_{2} / \mathrm{Ar}$ plasma etching, the previous $\mathrm{O}-\mathrm{O}$ bond peak was separated into two peaks corresponding to the $\mathrm{O}-\mathrm{O}$ bond and $\mathrm{O}-\mathrm{H}$ bond. Therefore, the intensity of the peak for the $\mathrm{O}-\mathrm{O}$ bond was dramatically increased. However, the O-O peak was shifted to $531.7 \mathrm{eV}$ and the other O-H peak appeared at $532.7 \mathrm{eV}$. We believe that the $\mathrm{O}-\mathrm{H}$ bond peak was due to contamination of the $\mathrm{ZnO}$ thin film surface due to its exposure to air. Also, we assume that the additive $\mathrm{N}_{2}$ gas combined with the $\mathrm{O}$ atoms. For this reason, the peak of the N-O bond appeared at $531.9 \mathrm{eV}$. There is also a possibility of $\mathrm{O}-\mathrm{Cl}$ bond formation, although this was not observed in this work. Figure 7(c) shows the XPS narrow scan spectra of the $\mathrm{Cl} 2 \mathrm{p}$ peaks of the $\mathrm{ZnO}$ thin films etched in $\mathrm{Cl}_{2} / \mathrm{Ar}$ and $\mathrm{N}_{2} / \mathrm{Cl}_{2} / \mathrm{Ar}$ plasma. As shown in Fig. 7 (c), the peak positions of $\mathrm{Cl} 2 \mathrm{p}$ were shifted by $\pm 0.5 \mathrm{eV}$ toward a lower binding energy compared with the binding energy $(198.5 \mathrm{eV})$ of the as-deposited sample and this chemical shift indicates that a chemical reaction exists on the surface of the $\mathrm{ZnO}$ thin films. The XPS Cl 2p peaks of the etched samples were decomposed into two peaks corresponding to the $\mathrm{Zn}-\mathrm{Cl}$ bond $(199.7 \mathrm{eV})$ and the $\mathrm{HCl} / \mathrm{H}_{2} \mathrm{O}$ bond $(198.3 \mathrm{eV})$. We assume that hydrogencontamination caused the $\mathrm{HCl} / \mathrm{H}_{2} \mathrm{O}$ peak. Also, Fig. 7(d) shows a $\mathrm{N}$ 1s peak in $\mathrm{N}_{2} / \mathrm{Cl}_{2} / \mathrm{Ar}$ plasma. In the $\mathrm{N}_{2} / \mathrm{Cl}_{2} / \mathrm{Ar}$ gas chemistry, a weak $\mathrm{N}$ 1s peak appeared at $402.9 \mathrm{eV}$. This peak was identified as $\mathrm{N}-\mathrm{O}$ bonds. In our opinion, the N-O bond can be explained by two factors. The first factor is $\mathrm{Zn}-\mathrm{O}$ bonds being broken by ion bombardment. The second factor is the possibility of a chemical reaction between nitrogen ions and the separated oxygen ions from the $\mathrm{Zn}-\mathrm{O}$ bonds. Also we expected to detect other nitrogen compound peak such as $\mathrm{Zn}_{3} \mathrm{~N}_{2}$ and $\mathrm{Zn}\left(\mathrm{NO}_{3}\right)_{2} \cdot 6 \mathrm{H}_{2} \mathrm{O}$ in the XPS narrow scan spectra of the $\mathrm{N} 1 \mathrm{~s}$, however we did not detect these other peaks [7-14].

\section{CONCLUSIONS}

We investigated etching characteristics on $\mathrm{ZnO}$ thin film in $\mathrm{N}_{2} / \mathrm{Cl}_{2} / \mathrm{Ar}$ plasmas using an inductive coupled plasma (ICP) system. It was found the additive $\mathrm{N}_{2}$ gas enhanced the etch rate. The maximum etch rate was $108.8 \mathrm{~nm} / \mathrm{min}$ at an $\mathrm{RF}$ power of $800 \mathrm{~W}$, a bias power of $400 \mathrm{~W}$, a gas mixture of $\mathrm{N}_{2} / \mathrm{Cl}_{2} / \mathrm{Ar}(15: 16: 4$ $\mathrm{sccm}$ ) and a process pressure of $1 \mathrm{~Pa}$. From the result of the XPS analysis, it was found that the $\mathrm{Zn} 2 \mathrm{p}$ spectra were shifted to lower binding energies and the $\mathrm{O} 1 \mathrm{~s}$ spectra were shifted to higher binding energies after the plasma treatments. Also, the N-O peak $(402.9 \mathrm{eV}, 530.8 \mathrm{eV})$ was obtained from the XPS narrow scan spectra of the $\mathrm{O} 1 \mathrm{~s}$ and $\mathrm{N}$ 1s peak. As a result, the $\mathrm{N}_{2}$ gas had the following two effects on the $\mathrm{ZnO}$ thin films: At a high bias power, the ion flux and ion bombardment of $\mathrm{N}$ ions promoted the physical etching mechanism with Ar ions. Secondly, the $\mathrm{N}_{2}$ gas resulted in chemical reactions leading to the formation of $\mathrm{N}_{\mathrm{x}} \mathrm{O}_{\mathrm{y}}$. For this reason, we suggest that the $\mathrm{N}_{2}$ gas contributed to both chemical and physical etching.

\section{REFERENCES}

[1] D. C. Look, Mater. Sci. Eng. B 80, 383 (2001) [DOI: 10.1016/ S0921-5107(00)00604-8].

[2] P. Zu, Z.K. Tang, G.K.L. Wong, M. Kawasaki, A. Ohtomo, K. Koinuma and Y. Sagawa, Solid State Commun. 103. 459 (1997) [DOI:10.1016/S0038-1098(97)00216-0].

[3] D. C. Look, D. C. Reynolds, J. R. Sizelove, R. L. Jones, C.W. Litton, G. Cantwell, W.C. Harsch, Solid State Commun. 105, 399 (1998) [DOI:10.1016/S0038-1098(97)10145-4].

[4] J. C. Woo, G. H. Kim, J. G. Kim, C. I. Kim, Surf. Coat. Technol. 202, 5705 (2008) [DOI:10.1016/j.surfcoat.2008.06.077].

[5] S. W. Na, M. H. Shin, Y. M. Chung, J.G. Jeung, J. H. Boo, N.E. Lee, Microelectron. Eng. 83, 328 (2006) [DOI:10.1016/ j.mee.2005.09.007].

[6] J. C. Woo, D. S. Um, C. I. Kim, Thin Solid Films 518, 2905 (2010) [DOI:10.1016/j.tsf.2009.10.144].

[7] W. T. Lim, L, Voss, R, Khanna, B. P. Gila, D. P. Norton, S. J. Pearton, F. Ren, Appl. Surf. Sci. 253, 889 (2006) [DOI: 10.1016/ j.apsusc.2006.01.037].

[8] X. Z. Fan, G. Xie, S. P. Chen, S. L. Gao, Q. Z. Shi, Thermochim. Acta. 413, 87 (2004) [DOI:10.1016/j.tca.2003.12.025].

[9] F. Zong, H. Ma, C. Xue, H. Zhuang, Xi. Zhang, H. Xiao, J. Ma, F. Ji, Solid State Commun. 132, 521 (2004) [DOI:10.1016/ j.ssc.2004.09.011].

[10] T. Suda, K. Kakishita, J. Appl. Phys. 99, 076101 (2006) [DOI:10.1063/1.2180541].

[11] N. Tabet, M. Faiz, A. Al-Oteibi, J. Electron Spectrosc. Relat. Phenom. 163, 15 (2008) [DOI:10.1016/j.elspec.2007.11.003].

[12] M. Futsuhara, K. Yoshioka, O. Takai, Thin Solid Films 322, 274 (1998) [DOI:10.1016/S0040-6090(97)00910-3].

[13] J. C. Woo, Y. H. Joo, J. S. Park, C. I. Kim, Trans. Electr. Electron. Mater. 144, 12 (2011).

[14] J. C. Woo, D. S. Um, C. I. Kim, Thin Solid Films 2905, 518 (2010) [DOI:10.1016/j.tsf.2009.10.144]. 